\title{
Iron Control in Atmospheric Acid Laterite Leaching
}

\author{
Ville Miettinen ${ }^{1, *}$, Jarno Mäkinen ${ }^{1}$, Eero Kolehmainen ${ }^{2}$, Tero Kravtsov ${ }^{2}$ and Lotta Rintala ${ }^{1(1)}$ \\ 1 VTT Technical Research Centre of Finland Ltd., P.O. Box 1000, FI-02044 VTT Espoo, Finland \\ 2 Outotec (Finland) Oy, P.O. Box 69, FI-28101 Pori, Finland \\ * Correspondence: ville.miettinen@vtt.fi; Tel.: +358-40-833-8096
}

Received: 7 May 2019; Accepted: 28 June 2019; Published: 30 June 2019

\begin{abstract}
Iron control in the atmospheric acid leaching (AL) of nickel laterite was evaluated in this study. The aim was to decrease acid consumption and iron dissolution by iron precipitation during nickel leaching. The combined acid leaching and iron precipitation process involves direct acid leaching of the limonite type of laterite followed by a simultaneous iron precipitation and nickel leaching step. Iron precipitation as jarosite is carried out by using nickel containing silicate laterite for neutralization. Acid is generated in the jarosite precipitation reaction, and it dissolves nickel and other metals like magnesium from the silicate laterite. Leaching tests were carried out using three laterite samples from the Agios Ioannis, Evia Island, and Kastoria mines in Greece. Relatively low acid consumption was achieved during the combined precipitation and acid leaching tests. The acid consumption was approximately $0.4 \mathrm{~kg}$ acid per $\mathrm{kg}$ laterite, whereas the acid consumption in direct acid leaching of the same laterite samples was approximately $0.6-0.8 \mathrm{~kg}$ acid per $\mathrm{kg}$ laterite. Iron dissolution was only $1.5-3 \%$ during the combined precipitation and acid leaching tests, whereas in direct acid leaching it was 15-30\% with the Agios Ioannis and Evia Island samples and $80 \%$ with the Kastoria sample.
\end{abstract}

Keywords: laterite; nickel; leaching; jarosite; precipitation

\section{Introduction}

Nickel is an essential element for modern industry with uses in stainless steel, nickel-based alloys, casting and alloy steels, electroplating, and rechargeable batteries [1,2]. The global plant production and demand for nickel in 2015 were $1.93 \mathrm{Mt}$ and $1.88 \mathrm{Mt}$, respectively [3]. Nickel mine production has increased steadily during the past 50 years; however, from 2008 onwards it has been more rapid. A further increase in demand may be encountered due to the higher production numbers of electric vehicles (EVs) as nickel is an essential battery chemical in typical lithium ion batteries [4]. The global reserves of nickel are estimated to be $74-80 \mathrm{Mt}$ including sulphide ores, laterites, and deep-sea nodules $[4,5]$. Even though laterites represent the vast majority of land-based reserves (approximately 72\%), until 2009, less than half of the global nickel production came from nickel laterite ores. Today, more than $60 \%$ of the world's nickel is derived from laterite resources [6-9]. To meet the rising nickel demand in the future, it is essential to develop further the methods that allow the economic utilization of nickel laterite ores.

Laterite deposits often contain several laterite types. Limonite laterites are found near the surface, while saprolite ores exist deeper and underneath the limonite ores [10]. The iron content of limonites is usually high and a significant amount of nickel is associated with it, whereas the iron content of saprolites is lower and the nickel is more often associated with silicates. Nickel is also found to be more readily leached from clay-like saprolite ores than limonites [6]. It is typical that Greek laterites contain some of the iron as hematite rather than goethite, which allows the leaching of nickel under conditions mild enough to avoid the high acid consumption associated with the substantial dissolution of iron [6]. 
At the moment, high-pressure acid leaching (HPAL) and pyrometallurgical treatment are the two main technologies for nickel laterite processing [11,12]. However, they have some disadvantages, such as high autoclave investment costs [6,13], technical problems [14], and high energy consumption [11]. In addition, these processes require rather high-grade nickel laterite ore for feasible operation. Ashok [11] has stated that the nickel content of ore should be over $1.4 \%$ for feasible HPAL processing and over $1.7 \%$ for pyrometallurgical processing.

The third option for nickel laterite processing is atmospheric acid leaching (AL). Investment costs of the process are lower than for pressure leaching, while the need for energy is significantly lower than for the pyrometallurgical operation [6]. Another advantage of AL is the potential to valorize the leach residues. Komnitsas et al. [15] found that column leaching residues can be alkali activated with the use of $\mathrm{NaOH}$ and $\mathrm{Na}_{2} \mathrm{SiO}_{3}$ as activators. Inorganic polymers with high strength, almost $40 \mathrm{MPa}$, can be produced, when $10 \mathrm{wt} \%$ metakaolin is added to the residue. These low toxicity products can be used as binders or building materials in several applications in the construction sector.

The main disadvantages of the AL process are high acid and neutralization agent consumptions. Usually, a significant fraction of total nickel content of laterite ore is associated with iron. Nickel may substitute iron in iron oxide minerals like goethite and thus selective leaching of nickel is not possible, as the chemical decomposition of the goethite is needed for nickel dissolution [10,11]. In the HPAL process, most of the dissolved iron will eventually precipitate as hematite, but in the case of the AL process, it will end up in the solution and must be removed before nickel recovery [16]. During laterite leaching, iron removal from the pregnant solution is usually carried out by using limestone [17] and, depending on the iron concentration, this can be a significant cost item. Therefore, effective iron control is necessary in order to minimize acid consumption and neutralization costs in atmospheric acid laterite leaching.

The main objective of this study was to combine nickel leaching and iron precipitation as sodium jarosite. The idea of combined leaching of limonite and using saprolite for neutralization has been patented by Arroy and Neudorf [18]. In this patent, limonite is dissolved with mineral acid and the saprolite type of laterite is used as neutralizing agent for jarosite precipitation. This invention decreases the use of additional neutralization agent for iron removal and thus improves the feasibility of the process. A quite similar idea, mostly for the sulfide type of nickel ores, has been patented by Leppinen et al. [19]. The patent's idea is to use poor nickel ore or waste for $\mathrm{pH}$ adjustment after the atmospheric acid leaching of nickel, cobalt, copper, or zinc. Iron dissolved in the atmospheric leaching precipitates and acid generated during the iron precipitation reaction is used for nickel dissolution from poor nickel ore. Jarosite precipitation is widely applied in hydrometallurgy to remove iron from the pregnant leach solution (PLS). In 2013, White and Gillaspie [20] reviewed comprehensively the acid leaching of nickel laterites with jarosite precipitation, including a discussion on the laterite profile as well as the disposition of other elements. In sulfuric acid solutions, sodium jarosite $\left(\mathrm{NaFe}_{3}\left(\mathrm{SO}_{4}\right)_{2}(\mathrm{OH})_{6}\right)$ forms in the presence of dissolved ferric $\left(\mathrm{Fe}^{3+}\right)$ and sodium $\left(\mathrm{Na}^{+}\right)$ions according to the following reaction:

$$
\mathrm{Na}^{+}+3 \mathrm{Fe}^{3+}+2 \mathrm{SO}_{4}{ }^{2-}+6 \mathrm{H}_{2} \mathrm{O} \rightarrow \mathrm{NaFe}_{3}\left(\mathrm{SO}_{4}\right)_{2}(\mathrm{OH})_{6}+6 \mathrm{H}^{+}
$$

Reaction (1) produces acid and has a positive effect on the acid consumption of the process. Favorable conditions for the reaction are $\mathrm{pH}<2.5$ and temperature $80-100{ }^{\circ} \mathrm{C}[21,22]$.

This study's specific aim was to investigate simultaneous nickel leaching and jarosite precipitation using Greek laterites. Investigating the characteristics of laterite ores and their suitability for simultaneous leaching and iron precipitation is the first step for the development of a feasible process. If iron control is successful in batch tests, pilot tests will be designed based on these results in the next phase of the research. 


\section{Materials and Methods}

\subsection{Materials}

Three nickel laterite ore samples were obtained from the GMM LARCO SA mines. The origin of the ores are the mines of Agios Ioannis (LAI) and Evia Island (LEV), in central Greece, and Kastoria (LK) in northwestern Greece. The comminution of the samples to $-300 \mu \mathrm{m}$ was carried out by Technical University of Crete, Chania, Greece. Each sample (i.e., LAI, LEV, and LK) was divided into sub-samples at VTT by using a sample divider (FRITSCH Rotary Sample Divider LABORETTE 27 and FRITSCH Vibratory Feeder LABORETTE 24, Pittsboro, NC, USA). The dry matter content (\% DM) of the samples was determined at VTT from the mass difference after drying the samples at $105{ }^{\circ} \mathrm{C}$. Dry matter contents were LAI 98.6\% DM, LEV 99.2\% DM, and LK 98.0\% DM.

The chemical and mineralogical composition of the samples was studied at Outotec, Espoo, Finland. The composition of the samples was analyzed by inductively coupled plasma optical emission spectrometry (ICP-OES) after total dissolution. Sulfur and carbon analysis was measured using an Eltra CS-2000 automatic analyzer. The quantity of silica was analyzed colorimetrically using a Hach DR 5000 UV-Vis spectrophotometer. The chemical compositions of the laterite samples are presented in Table 1. X-ray diffraction (XRD) analysis for the ores was carried out at Outotec, Espoo, Finland and the analysis for the leach residues was performed at Eurofins Expert Services Oy, Espoo, Finland.

In addition to XRD analysis used to determine the main minerals of each ore sample, polished sections were prepared from each sample, and they were examined by a JEOL JSM-7000F field emission scanning electron microscope (FE-SEM) (Tokyo, Japan) equipped with an Oxford Instruments energy dispersive spectrometer (EDS) and wavelength dispersive spectrometer (WDS). The imaging and both EDS and WDS analyses were performed under routine conditions using $20 \mathrm{kV}$ acceleration voltage and $1 \mathrm{nA}$ beam current for EDS analyses and $20 \mathrm{nA}$ beam current for WDS analyses. The minerals were identified from the EDS analyses and their nickel content was analyzed by WDS using a pure nickel metal standard. Mineral quantification was performed using HSC Chemistry ${ }^{\circledR}$ (Module version 9.3.0, Outotec, Espoo, Finland) using mineralogical analyses gathered from all of the aforementioned methods. The mineralogy of the laterite samples and the distribution of nickel within the minerals are presented in Table 2.

Table 1. Chemical composition of the laterite samples.

\begin{tabular}{|c|c|c|c|}
\hline Laterite & LAI & LEV & LK \\
\hline Element & $\%$ & $\%$ & $\%$ \\
\hline $\mathrm{Ni}^{*}$ & 1.00 & 0.843 & 0.939 \\
\hline $\mathrm{Fe}^{*}$ & 31.6 & 26.3 & 13.2 \\
\hline $\mathrm{Al}$ * & 9.58 & 2.62 & 0.388 \\
\hline $\mathbf{M g}$ * & 1.1 & 2.16 & 12.8 \\
\hline $\mathrm{Na}^{*}$ & $<0.1$ & $<0.1$ & $<0.1$ \\
\hline $\mathbf{P} *$ & 0.025 & $<0.02$ & $<0.02$ \\
\hline $\mathbf{K}^{*}$ & 0.16 & 0.539 & $<0.1$ \\
\hline $\mathrm{Ca}$ * & 2.2 & 2.08 & 3.37 \\
\hline $\mathbf{T i}^{*}$ & 0.55 & 0.142 & 0.025 \\
\hline $\mathrm{Cr} *$ & 1.27 & 1.72 & 0.554 \\
\hline Mn * & 0.179 & 0.167 & 0.179 \\
\hline $\mathrm{Co}^{*}$ & 0.062 & 0.042 & 0.029 \\
\hline $\mathrm{Cu}^{*}$ & $<0.005$ & $<0.01$ & $<0.01$ \\
\hline$Z_{n}$ * & 0.015 & 0.015 & 0.009 \\
\hline As * & 0.02 & $<0.02$ & $<0.02$ \\
\hline$C^{* *}$ & 0.69 & 0.76 & 1.1 \\
\hline$S^{* *}$ & 0.02 & 0.09 & $<0.02$ \\
\hline $\mathrm{SiO}_{2} * * *$ & 16.3 & 40.7 & 37.1 \\
\hline
\end{tabular}


Table 2. Mineralogy of the samples and distribution of nickel in each main phase.

\begin{tabular}{ccccccc}
\hline \multirow{2}{*}{ Mineralogy } & LAI & Ni & LEV & Ni & LK & Ni \\
\cline { 2 - 7 } & wt \% & dist. $\%$ & wt \% & dist. \% & wt \% & dist. \% \\
\hline Hematite & 45.4 & 16 & 44.6 & 47 & & \\
Goethite & & & & & 19.5 & 24 \\
Al-clays and Al-hydroxides * & 21.1 & 60 & & & & \\
Smectite group minerals & 5.5 & 22 & 2.1 & 13 & & \\
Primary serpentinite silicates ** & 12.8 & 1 & 8.5 & 39 & 67.6 & 75 \\
Quartz & 6 & & 34.4 & & 3.2 & \\
Carbonates & 5.8 & & 3.3 & & 7.6 & \\
Chromite & 2.6 & $<1$ & 3.5 & $<1$ & 1.7 & $<1$ \\
Magnetite & 0.8 & $<1$ & 0.7 & $<1$ & 0.5 & $<1$ \\
\hline
\end{tabular}

* The content of aluminum clays and aluminum (oxy)hydroxides cannot be assessed with the characterization methods used; ** LAI, chlorite and anthophyllite; LEV, chlorite; LK, lizardite and anthophyllite.

Based on mineralogical analyses, LAI is composed mainly of hematite, clays, and primary serpentinite silicates. Nickel is distributed into mainly (60\%) Al-clays and Al-hydroxides and the rest is distributed into smectites and hematite. Based on the mineralogical analyses of the samples, LAI was found to be a mixture of different laterization profiles. It could be defined as an aluminous laterite or a bauxite, based on its high $\mathrm{Al}$ content. However, the occurrence of smectites, primary serpentinite silicates, and the high contents of Fe and hematite are typical features of saprolitic and limonitic laterization profiles as well as weathered serpentinite.

LEV is composed mainly of hematite and quartz. Minor chlorite, smectite, chromite, and carbonates comprise the rest of the sample. With respect to the nickel, $47 \%$ of it is distributed into hematite, $39 \%$ into chlorite, and 13\% into the smectites. Based on the mineralogy, LEV was mined from a transitional zone, between limonitic and saprolitic profiles.

In the case of $\mathrm{LK}, 68 \%$ of it is composed of primary serpentinite silicates (i.e., lizardite and anthophyllite), $20 \%$ of goethite, $7.6 \%$ of calcite and dolomite, $3.2 \%$ of quartz, and $1.7 \%$ of chromite. LK can be categorized as weathered serpentinite laterite. Its nickel is mainly $(75 \%)$ distributed into the primary serpentinite silicates and secondarily $(24 \%)$ into goethite.

Theoretical maximum acid consumptions of the laterite samples are presented in Table 3 . The acid consumption is calculated for each metal assuming that the metal dissolution is $100 \%$. It can be seen from the table that acid-consuming metals are quite different in each sample. The main acid-consuming metals in the LAI sample are iron and aluminum, while the aluminum content of the LEV sample is very low and iron is the only significant acid-consuming metal. Acid consumption in both LEV and LAI samples is mainly caused by iron, but in case of the LK sample, the main acid-consuming metal is magnesium.

Table 3. Theoretical maximum acid consumption of Agios Ioannis (LAI), Evia Island (LEV) and Kastoria (LK) laterites as grams sulfuric acid per kg laterite. Metal dissolution to solution is assumed to be $100 \%$.

\begin{tabular}{cccc}
\hline & LAI & LEV & LK \\
\hline & $\mathbf{H}_{\mathbf{2}} \mathbf{S O}_{\mathbf{4}} \mathbf{g} /$ laterite $\mathbf{~ k g}$ & $\mathbf{H}_{\mathbf{2}} \mathbf{S O}_{\mathbf{4}} \mathbf{g} /$ laterite $\mathbf{~ k g}$ & $\mathbf{H}_{\mathbf{2}} \mathbf{S O}_{\mathbf{4}} \mathbf{g} /$ laterite $\mathbf{~ g}$ \\
\hline $\mathrm{Ni}$ & 16.7 & 14.0 & 15.7 \\
$\mathrm{Fe}$ & 832 & 693 & 348 \\
$\mathrm{Al}$ & 522 & 143 & 21.3 \\
$\mathrm{Mg}$ & 44.4 & 87.2 & 517 \\
$\mathrm{Ca}$ & 53.8 & 50.9 & 82.5 \\
$\mathrm{Mn}$ & 3.21 & 3.03 & 3.21 \\
Total & 1470 & 991 & 987 \\
\hline
\end{tabular}




\subsection{Leaching of Laterite Ores}

The aim of the study was to determine whether a suitable feed consisting of LAI, LEV, and LK ores would result in iron control during atmospheric acid leaching. In the first phase of the tests, the effect of $\mathrm{pH}$ on nickel and iron dissolution was determined. The leaching test setup is presented in Figure 1. In the experiments, a Mettler Toledo T70 titrator (Columbus, OH, USA) was used for $\mathrm{H}_{2} \mathrm{SO}_{4}$ feed and a Consort $\mathrm{C} 3040$ was used to monitor $\mathrm{pH}$, oxidation/reduction potential (ORP), and temperature on-line. Manufacturer and model of the electrodes were Van London Phoenix PH7V110-10B-300 (pH electrodes) and Van London Phoenix RP75130-10B-300 (oxidation/reduction electrodes) (Houston, TX, USA). The reactor mass was monitored by a balance, Shimadzu BW22KH (Kyoto, Japan) or Hottinger Baldwin Messtechnik GmbH (Darmstadt, Germany), connected to a monitor, Gottl. Kern \& Sohn GmbH (Balingen, Germany). In the experiments where LK was added, the amount of LK addition was examined on-line by a balance, Precisa ES 8200C-DR (Aldingen, Germany). Chemicals used in the experiments were $\mathrm{H}_{2} \mathrm{SO}_{4}$ (Merck EMSURE ${ }^{\circledR}$ ISO sulfuric acid 95-97\% for analysis) and $\mathrm{Na}_{2} \mathrm{SO}_{4}$ (Sigma-Aldrich sodium sulfate ACS reagent $\geq 99.0 \%$ anhydrous granular, St. Louis, MO, USA).

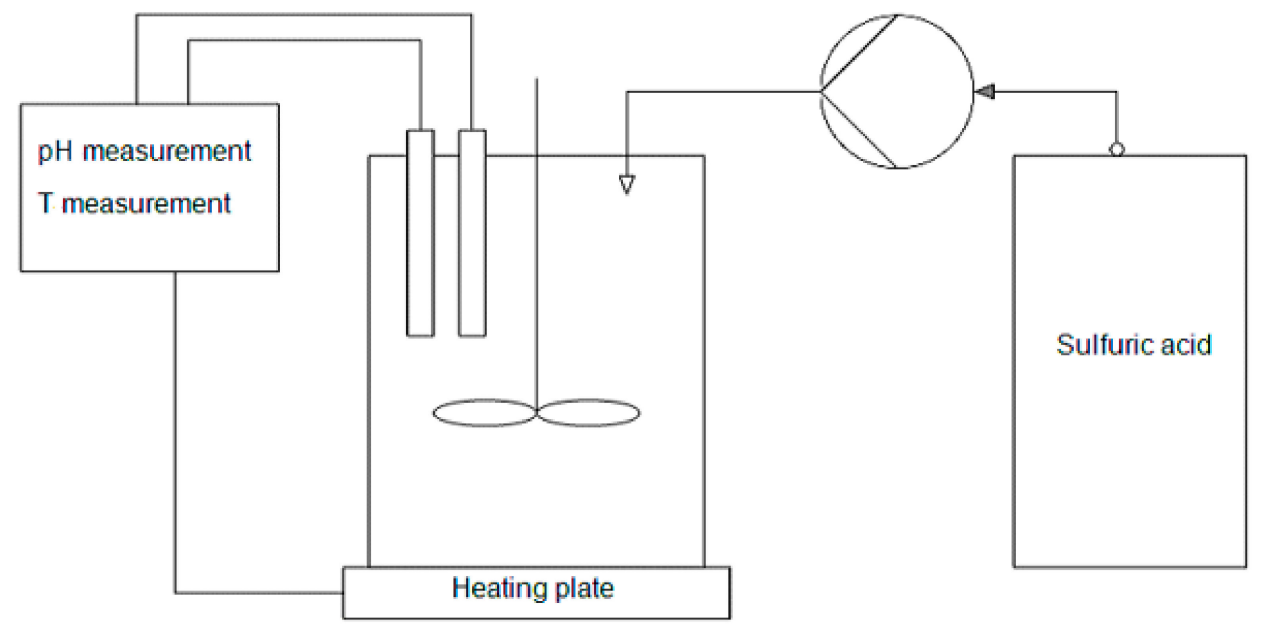

Figure 1. Experimental setup used in the acid consumption test. A $5 \mathrm{~L}$ reactor (Ti, Gr. 2) on the heating plate is placed on top of the balance. Titrator is on the right.

The characteristic leaching behavior of each laterite was studied under the following leaching conditions: $\mathrm{pH} 0.25-1.5, \mathrm{~T}=90^{\circ} \mathrm{C}, \mathrm{S} / \mathrm{L}=30 \%$, particle size $-300 \mu \mathrm{m}, 800 \mathrm{rpm}$. Experiments were carried out in $5 \mathrm{~L}$ reactors for $8 \mathrm{~h}$. An experiment started $(\mathrm{t}=0 \mathrm{~h})$ when the target $\mathrm{pH}$ was reached.

Based on the results of the $8 \mathrm{~h}$ leaching tests, two-phase leaching tests were designed. These experiments were carried out in $\mathrm{pH} 0.75-1.8, \mathrm{~T}=90^{\circ} \mathrm{C}, \mathrm{S} / \mathrm{L}=30 \%$, particle size $-300 \mu \mathrm{m}, 800 \mathrm{rpm}, 48 \mathrm{~h}$. In the first part of these tests, LAI or LEV were first leached separately at $\mathrm{pH} 0.75$. LAI was leached for $24 \mathrm{~h}$ and LEV for $6 \mathrm{~h}$. In the second part of the tests, leaching was continued for the following $24 \mathrm{~h}$ in $\mathrm{pH} 1.8$ with $\mathrm{LK}$ addition. In the tests, $\mathrm{pH}$ was controlled by $\mathrm{LK}$ additions and $\mathrm{H}_{2} \mathrm{SO}_{4}$. Iron precipitation was ensured by $\mathrm{Na}_{2} \mathrm{SO}_{4}$ additions before the $\mathrm{LK}$ feed. The amounts were $235 \mathrm{~g}$ of $\mathrm{Na}_{2} \mathrm{SO}_{4}$ for LAI and $150 \mathrm{~g}$ for LEV.

After leaching, the slurry was filtered (pore size of $0.45 \mu \mathrm{m}$ ) using a Büchner funnel and a filter flask. The leach residue was washed with acidic water ( $\mathrm{pH} 1-1.5)$, followed by a washing with deionized water. The washed residue was dried and weighed.

\subsection{Analytical Methods}

Solution samples were analyzed with ICP-OES and ICP-MS. Microwave-assisted digestion was performed with a mixture of $\mathrm{HF}, \mathrm{HNO}_{3}$, and $\mathrm{HCl}$ according to $\mathrm{EN} 13656$ and the subsequent determination of elements was applied to solid samples. These analyses were carried out at Labtium Oy, Espoo, Finland. 


\section{Results and Discussion}

\subsection{Acid Leaching of Greek Laterites}

Sulfuric acid leaching tests were carried out for each LAI, LEV and LK laterite sample. The idea of the leaching tests was to find suitable leaching $\mathrm{pH}$ for each laterite and determine acid consumption of direct acid leaching. Nickel dissolution during the $8 \mathrm{~h}$ leaching tests is presented in Figure 2 and iron dissolution in Figure 3. The nickel and iron recoveries are shown in Table 4.

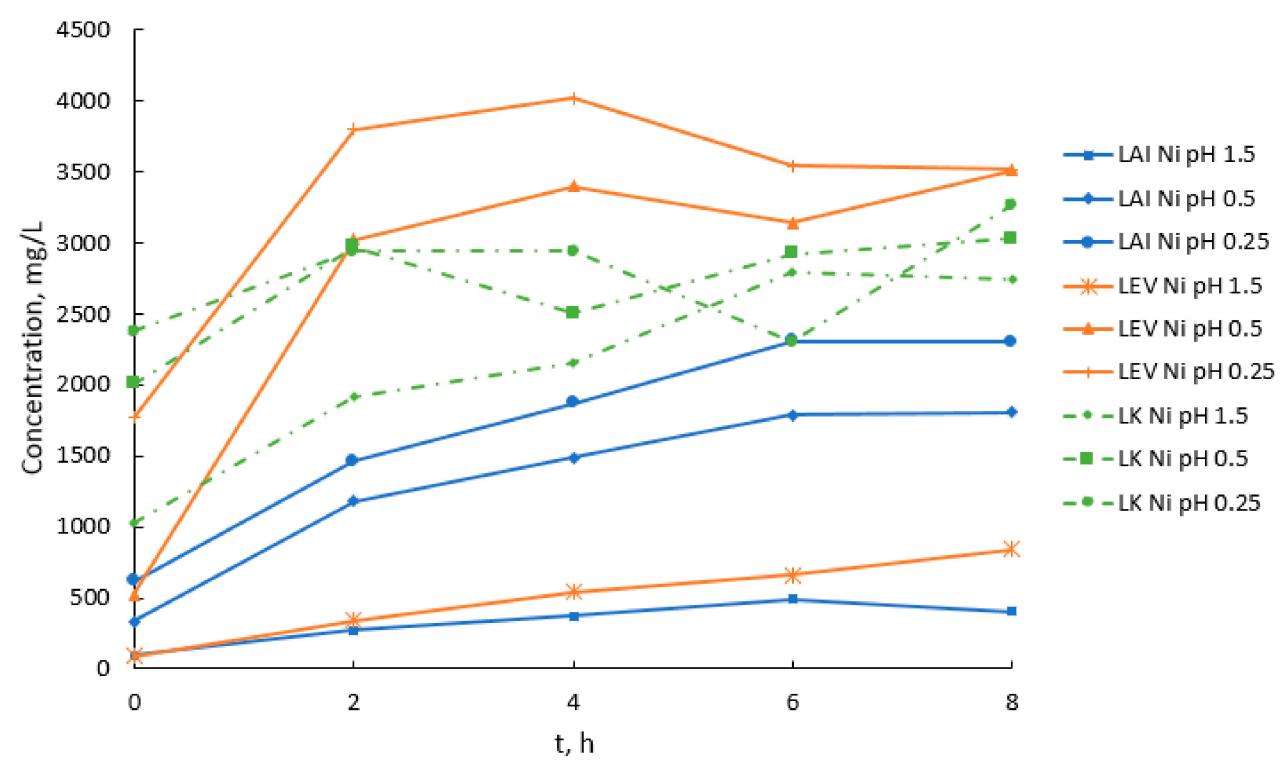

Figure 2. Evolution of Ni concentration vs. time during leaching of LAI, LEV, and LK laterites in $\mathrm{pH}$ $0.25,0.5$, and 1.5. Parameters used in the experiments: $90{ }^{\circ} \mathrm{C}, \mathrm{S} / \mathrm{L}=30 \%, 800 \mathrm{rpm}$. pH was maintained by $\mathrm{H}_{2} \mathrm{SO}_{4}$ addition.

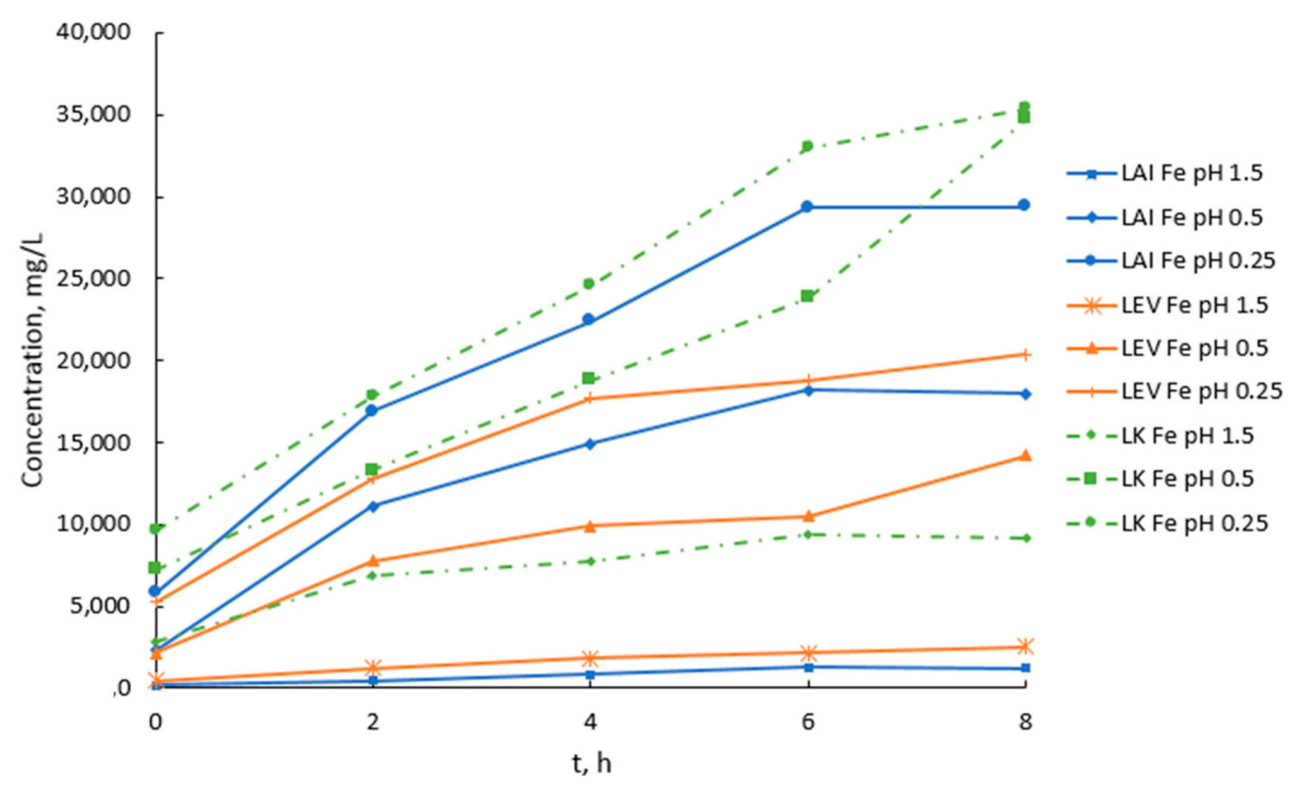

Figure 3. Evolution of Fe concentration vs. time during leaching of LAI, LEV, and LK laterites in $\mathrm{pH}$ $0.25,0.5$ and 1.5. Parameters used in the experiments: $90{ }^{\circ} \mathrm{C}, \mathrm{S} / \mathrm{L}=30 \%, 800 \mathrm{rpm}$. $\mathrm{pH}$ was maintained by $\mathrm{H}_{2} \mathrm{SO}_{4}$ addition. 
Table 4. Nickel and iron yields to solution in acid leaching test of LAI, LEV, and LK laterite in pH 0.25, 0.5 and 1.5. Parameters used in the experiments: $90^{\circ} \mathrm{C}, \mathrm{S} / \mathrm{L}=30 \%, 800 \mathrm{rpm}$. $\mathrm{pH}$ was maintained by $\mathrm{H}_{2} \mathrm{SO}_{4}$ addition.

\begin{tabular}{cccccccccc}
\hline & $\begin{array}{c}\text { LAI, } \\
\text { pH 1.5 }\end{array}$ & $\begin{array}{c}\text { LAI, } \\
\text { pH 0.5 }\end{array}$ & $\begin{array}{c}\text { LAI, } \\
\text { pH 0.25 }\end{array}$ & $\begin{array}{c}\text { LEV, } \\
\text { pH 1.5 }\end{array}$ & $\begin{array}{c}\text { LEV, } \\
\text { pH 0.5 }\end{array}$ & $\begin{array}{c}\text { LEV, } \\
\text { pH 0.25 }\end{array}$ & $\begin{array}{c}\text { LK, } \\
\text { pH 1.5 }\end{array}$ & $\begin{array}{c}\text { LK, } \\
\text { pH 0.5 }\end{array}$ & $\begin{array}{c}\text { LK, } \\
\text { pH 0.25 }\end{array}$ \\
\hline $\mathrm{Ni}, \%$ & 12.0 & 54.3 & 69.0 & 30.1 & $>100.0$ & $>100.0$ & 87.5 & 96.8 & $>100.0$ \\
$\mathrm{Fe}, \%$ & 1.2 & 17.1 & 27.9 & 2.9 & 16.2 & 23.3 & 20.9 & 78.9 & 80.5 \\
\hline
\end{tabular}

The mineralogical study shows that a significant portion of nickel in LAI and LEV laterites is associated with iron oxides and iron-containing silicates and it seems, based on the leaching results, that a partial decomposition of these minerals is needed for nickel liberation and dissolution. Nickel dissolution kinetics in LEV leaching tests was fast and maximum nickel dissolution was achieved only four hours from the beginning of the test. Iron dissolution was relatively low in the LEV leaching tests. Based on these results, it can be concluded that, in LEV laterite, nickel is not substituted into goethite like in many limonite laterites [6,7]. In the LAI leaching tests, the nickel was harder to leach and was associated with more refractory host minerals. Nickel dissolution from LK laterite was found to differ compared to nickel dissolution from LAI and LEV samples. Most of the nickel was dissolved already at $\mathrm{pH} 1.5$. Most of the $\mathrm{LK}(67.6 \mathrm{wt} \%)$ consists of primary serpentinite silicates, such as lizardite $\left(\mathrm{Mg}_{3} \mathrm{Si}_{2} \mathrm{O}_{5}(\mathrm{OH})_{4}\right)$ and anthophyllite $\left(\mathrm{Mg}_{7}\left(\mathrm{Si}_{8} \mathrm{O}_{22}\right)(\mathrm{OH})_{2}\right)$, and $75 \%$ of the nickel is associated with these silicates. Only $19.5 \mathrm{wt} \%$ of LK consists of hematite and other iron oxides, and $24 \%$ of the nickel is associated with these oxides. Therefore, it is clear that iron dissolution is not associated with nickel dissolution.

It can be seen from Figures 2 and 3 that nickel dissolution of LAI and LEV laterites at pH 1.5 is much lower than at $\mathrm{pH} 0.5$ and 0.25 . Higher acidity was needed for efficient nickel dissolution for LAI and LEV laterites. In contrast, nickel from LK dissolved considerably already at $\mathrm{pH} 1.5$ and the dissolution was quite similar in all LK leaching tests. Some oscillation in the nickel concentrations was observed; this is most likely related to the addition of acid followed by the subsequent dissolution of metal. Nickel yields at pH 1.5 were $12 \%$ for LAI, 30.1\% for LEV, and $87.5 \%$ for LK (see Table 4). However, the iron dissolution of LK was significantly higher when the $\mathrm{pH}$ was $0.25-0.5$ compared to the test carried out at 1.5 .

When comparing the nickel and iron dissolution at $\mathrm{pH} 0.5$ and 0.25 (see Figures 2 and 3), it is observed that nickel cannot be selectively dissolved because a significant fraction of iron will also dissolve together with the nickel. Theoretical acid consumptions for the laterite samples are presented in Table 3 and actual acid additions after $8 \mathrm{~h}$ of leaching are presented in Table 5. The actual amounts of acid consumed in the leaching reactions are presented in Figure 4. Acid addition was calculated based on the amount of sulfuric acid $(100 \%)$ added to the leaching reactor divided by the amount of dry laterite added to the reactor. Acid consumption was calculated from the metal dissolution rate, assuming that $\mathrm{Mg}, \mathrm{Mn}$, and $\mathrm{Ni}$ consume $1 \mathrm{~mol}$ acid per $1 \mathrm{~mol}$ metal and that $\mathrm{Fe}$ and $\mathrm{Al}$ consume $1.5 \mathrm{~mol}$ acid per $1 \mathrm{~mol}$ metal. It was found out that acid addition in both LAI and LEV tests was quite low, being only approximately $120-140 \mathrm{~kg}$ sulfuric acid per t laterite when the $\mathrm{pH}$ was 1.5 . Acid additions and calculated acid consumption values are quite similar, indicating that the amount of unreacted acid is very low. Acid addition in the LK leaching test was significantly higher than in LAI and LEV leaching at the same $\mathrm{pH}$, being $650 \mathrm{~kg}$ sulfuric acid per $\mathrm{t}$ laterite. The metal concentrations in the final leach solutions are shown in Table 6. It can be concluded that the high acid addition of LK laterite at $\mathrm{pH} 1.5$ is mainly due to high magnesium dissolution. Based on the acid consumption calculation, nearly $80 \%$ of the acid was consumed in the magnesium dissolution reactions. It seems that dissolution kinetics of magnesium from silicates is relatively fast since most of acid was consumed during the two hours from the beginning of the test. Acid addition in the LK leaching tests was close to the theoretical maximum acid consumption when $\mathrm{pH}$ was 0.5 or 0.25 . Acid addition in the LAI and LEV leaching tests was low compared to the theoretical maximum consumption. This is mainly 
explained by the relatively low iron dissolutions. Iron, however, was still the main acid-consuming metal in both the LAI and LEV leaching tests. Approximately 30\% of the total acid consumption was caused by iron dissolution in the LEV leaching test and approximately $40 \%$ in the LAI leaching test. There are significant differences between acid addition and calculated acid consumption values at $\mathrm{pH}$ 0.5 and 0.25 . There was some oscillation in the acid addition and calculated acid consumption values, but it seems that the amount of unreacted acid at $\mathrm{pH} 0.5$ is approximately $50 \mathrm{~kg}$ per $\mathrm{t}$ ore, whereas at $\mathrm{pH} 0.5$ it is somewhat higher at over $100 \mathrm{~kg}$ per $\mathrm{t}$ ore.

Table 5. Cumulative acid additions $\left(\mathrm{H}_{2} \mathrm{SO}_{4} \mathrm{~kg} / \mathrm{t}\right.$ dry ore) during leaching of the LAI, LEV, and LK laterites in $\mathrm{pH} 0.25,0.5$, and 1.5. Parameters used in the experiments: $90{ }^{\circ} \mathrm{C}, \mathrm{S} / \mathrm{L}=30 \%$, $800 \mathrm{rpm}$. $\mathrm{pH}$ was maintained by $\mathrm{H}_{2} \mathrm{SO}_{4}$ addition.

\begin{tabular}{|c|c|c|c|c|}
\hline \multirow{2}{*}{$\mathrm{pH}$} & Time & LAI & LEV & LK \\
\hline & $\mathbf{h}$ & $\mathrm{H}_{2} \mathrm{SO}_{4} \mathrm{~kg} / \mathrm{t}$ dry ore & $\mathrm{H}_{2} \mathrm{SO}_{4} \mathrm{~kg} / \mathrm{t}$ dry ore & $\mathrm{H}_{2} \mathrm{SO}_{4} \mathrm{~kg} / \mathrm{t}$ dry ore \\
\hline \multirow{4}{*}{1.5} & 2 & 72.9 & 89.3 & 532 \\
\hline & 4 & 92.5 & 115 & 597 \\
\hline & 6 & 109 & 126 & 647 \\
\hline & 8 & 123 & 142 & 647 \\
\hline \multirow{4}{*}{0.5} & 2 & 305 & 343 & 787 \\
\hline & 4 & 372 & 403 & 832 \\
\hline & 6 & 395 & 455 & 1120 \\
\hline & 8 & 442 & 455 & 1120 \\
\hline \multirow{4}{*}{0.25} & 2 & 463 & 4940 & 880 \\
\hline & 4 & 532 & 529 & 911 \\
\hline & 6 & 605 & 576 & 945 \\
\hline & 8 & 649 & 593 & 951 \\
\hline
\end{tabular}

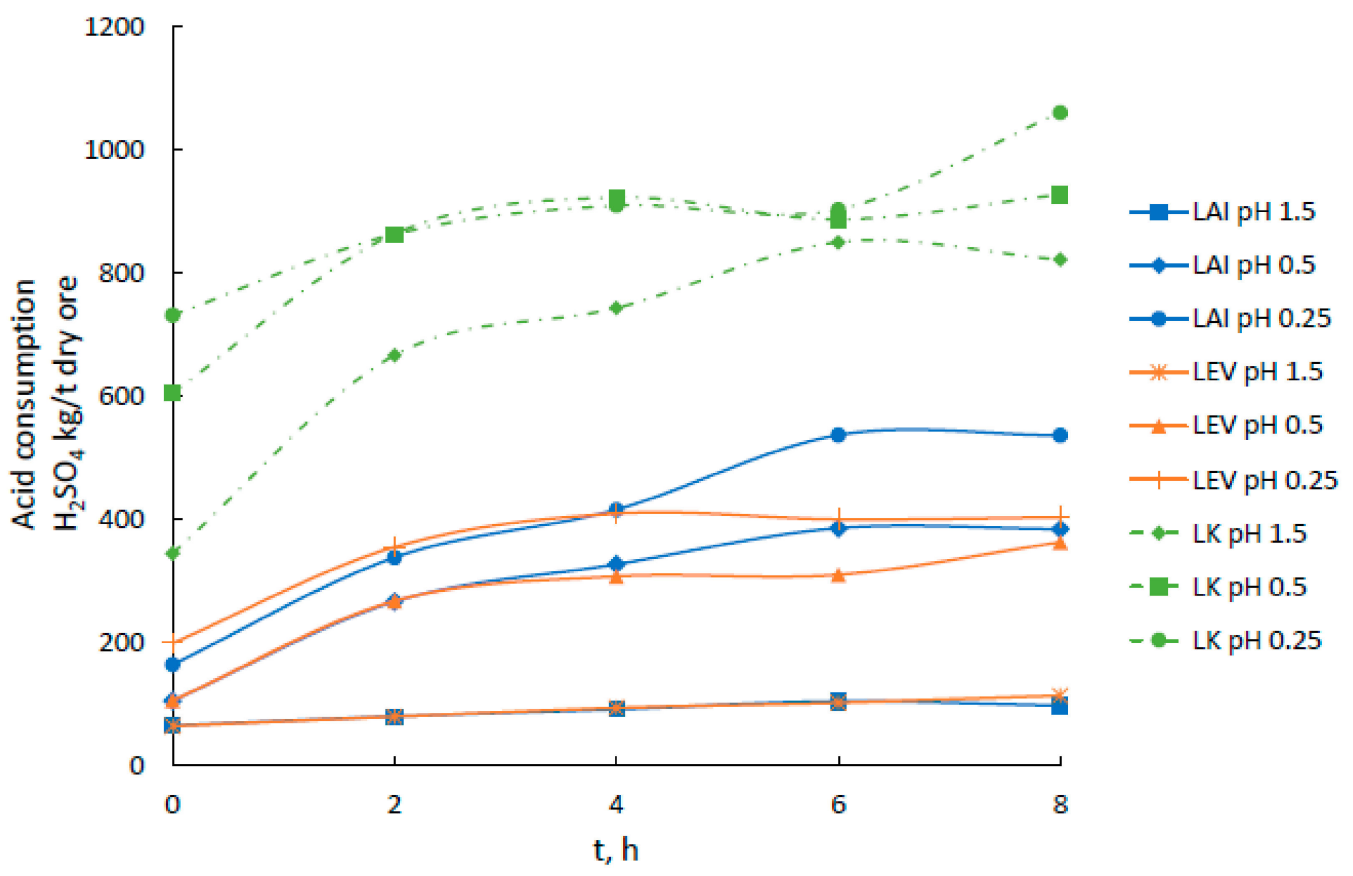

Figure 4. Calculated acid consumptions $\left(\mathrm{H}_{2} \mathrm{SO}_{4} \mathrm{~kg} / \mathrm{t}\right.$ dry ore) during leaching of the LAI, LEV, and LK laterites in $\mathrm{pH} 0.25,0.5$, and 1.5. Parameters used in the experiments: $90^{\circ} \mathrm{C}, \mathrm{S} / \mathrm{L}=30 \%, 800 \mathrm{rpm}$. $\mathrm{pH}$ was maintained by $\mathrm{H}_{2} \mathrm{SO}_{4}$ addition. Acid consumptions were calculated based on solution analyses. 
Table 6. Dissolutions of $\mathrm{Ni}, \mathrm{Co}, \mathrm{Fe}, \mathrm{Ca}, \mathrm{Mg}$, and $\mathrm{Al}$ and efficiency of $\mathrm{H}_{2} \mathrm{SO}_{4}$ leaching of the LAI, $\mathrm{LEV}$, and LK laterites under the following conditions: $\mathrm{pH} 0.25,0.5$, and $0.25,90^{\circ} \mathrm{C}, \mathrm{S} / \mathrm{L}=30 \%, 8 \mathrm{~h}$. Selectivity of $\mathrm{Ni}$ is compared over $\mathrm{Fe}, \mathrm{Mg}$, and $\mathrm{Al}$ using the respective ratios and concentrations in the pregnant leach solution (PLS).

\begin{tabular}{ccccccccccc}
\hline $\begin{array}{c}\text { Laterite } \\
\text { Ore }\end{array}$ & $\mathbf{p H}$ & $\begin{array}{c}\mathbf{N i} \\
(\mathbf{m g} / \mathbf{L})\end{array}$ & $\begin{array}{c}\mathrm{Co} \\
(\mathbf{m g} / \mathbf{L})\end{array}$ & $\begin{array}{c}\mathbf{F e} \\
(\mathbf{m g} / \mathbf{L})\end{array}$ & $\begin{array}{c}\mathrm{Ca} \\
(\mathbf{m g} / \mathbf{L})\end{array}$ & $\begin{array}{c}\mathbf{M g} \\
(\mathbf{m g} / \mathbf{L})\end{array}$ & $\begin{array}{c}\mathbf{A l} \\
(\mathbf{m g} / \mathbf{L})\end{array}$ & $\mathbf{N i} / \mathbf{F e}$ & $\mathbf{N i} / \mathbf{M g}$ & $\mathbf{N i} / \mathbf{A l}$ \\
\hline LAI & 1.5 & 401 & 60 & 1220 & 447 & 591 & 1560 & 0.33 & 0.68 & 0.26 \\
LAI & 0.5 & 1810 & 156 & 18,000 & 515 & 2630 & 9020 & 0.10 & 0.69 & 0.20 \\
LAI & 0.25 & 2300 & 174 & 29,400 & 405 & 2990 & 12,400 & 0.08 & 0.77 & 0.19 \\
LEV & 1.5 & 845 & 27 & 2550 & 721 & 2350 & 1440 & 0.33 & 0.36 & 0.59 \\
LEV 1 & 0.5 & 3510 & 136 & 14,200 & 518 & 8040 & 5210 & 0.25 & 0.44 & 0.67 \\
LEV & 0.25 & 3520 & 77 & 20,400 & 417 & 7540 & 5070 & 0.17 & 0.47 & 0.69 \\
LK & 1.5 & 2740 & 63 & 9210 & 373 & 53,400 & 437 & 0.30 & 0.05 & 6.27 \\
LK & 0.5 & 3030 & 60 & 34,700 & 159 & 44,900 & 754 & 0.09 & 0.07 & 4.02 \\
LK & 0.25 & 3270 & 85 & 35,400 & 177 & 55,300 & 785 & 0.09 & 0.06 & 4.17 \\
\hline
\end{tabular}

${ }^{1}$ Sample treatment from $\mathrm{t}=8 \mathrm{~h}$ was unsuccessful. Analysis was done after $26.5 \mathrm{~h}$. In this experiment, $8 \mathrm{~h}$ of leaching was performed at $90^{\circ} \mathrm{C}$, and then the slurry was agitated without heating overnight.

The $8 \mathrm{~h}$ leaching experiments showed that nickel from LK laterite can be dissolved at $\mathrm{pH}$ 1.5, which is also a suitable $\mathrm{pH}$ for jarosite precipitation. It was found that LAI and LEV need more acidic conditions, while simultaneous nickel leaching and jarosite precipitation in these cases is not possible. The combined leaching and precipitation tests were designed based on these facts.

\subsection{Combined Leaching and Iron Precipitation}

The aim of the combined leaching and iron precipitation tests was to dissolve nickel from LEV or LAI laterite first in a lower $\mathrm{pH}$ and then to increase the $\mathrm{pH}$ by LK addition. This would allow for the simultaneous dissolution of nickel from LK and precipitation of iron from the solution.

Combined tests began by leaching LAI or LEV laterites at $\mathrm{pH} 0.75$, followed by an increase of $\mathrm{pH}$ to 1.8 by LK laterite addition. Leaching was continued until a total leaching time of $48 \mathrm{~h}$ was reached. The duration of the first leaching phase was decided for LAI and LEV based on the results of the $8 \mathrm{~h}$ experiments. As metallurgical process design involves balancing costs and yields, the question of whether leaching at $\mathrm{pH} 0.75$ would be sufficient for nickel dissolution form LAI and LEV was studied. In Figure 2, it was seen that at $\mathrm{pH} 0.5$ and 0.25 , a significant dissolution of nickel from LEV occurred already after $2 \mathrm{~h}$ leaching. Therefore, the leaching time for LEV was determined to be $6 \mathrm{~h}$. Based on the $8 \mathrm{~h}$ test, nickel dissolution from LAI was slower than from LEV. As seen from Table 4 , the nickel yield from LAI after $8 \mathrm{~h}$ increased from $54.3 \%$ to $69.0 \%$ when $\mathrm{pH}$ was decreased from 0.5 to 0.25 . Thus, the leaching time selected for LAI at pH 0.75 was $24 \mathrm{~h}$.

$\mathrm{Ni}, \mathrm{Co}, \mathrm{Fe}, \mathrm{Ca}, \mathrm{Mg}$, and $\mathrm{Al}$ dissolution, acid addition, and LK consumption during the combined leaching, and the iron precipitation experiments are shown in Figures 5 and 6 as well as in Table 7 . A clear decrease in iron concentration is noticed after LK addition. In both cases, iron concentration after leaching of LAI or LEV was over $10 \mathrm{~g} / \mathrm{L}$, and after the LK addition the iron concentration decreased to approximately $2 \mathrm{~g} / \mathrm{L}$. Table 7 shows the efficiency of $\mathrm{H}_{2} \mathrm{SO}_{4}$ leaching of laterites in combined nickel leaching and iron precipitation tests, by comparing the selectivity of $\mathrm{Ni}$ over $\mathrm{Fe}, \mathrm{Mg}$, and $\mathrm{Al}$ using the respective ratios and concentrations in the PLS. As can been seen in Figures 5 and 6, iron precipitation was clearly observed after LK addition. In Table 7 , this is shown also by the high $\mathrm{Ni} / \mathrm{Fe}$ selectivity values. 


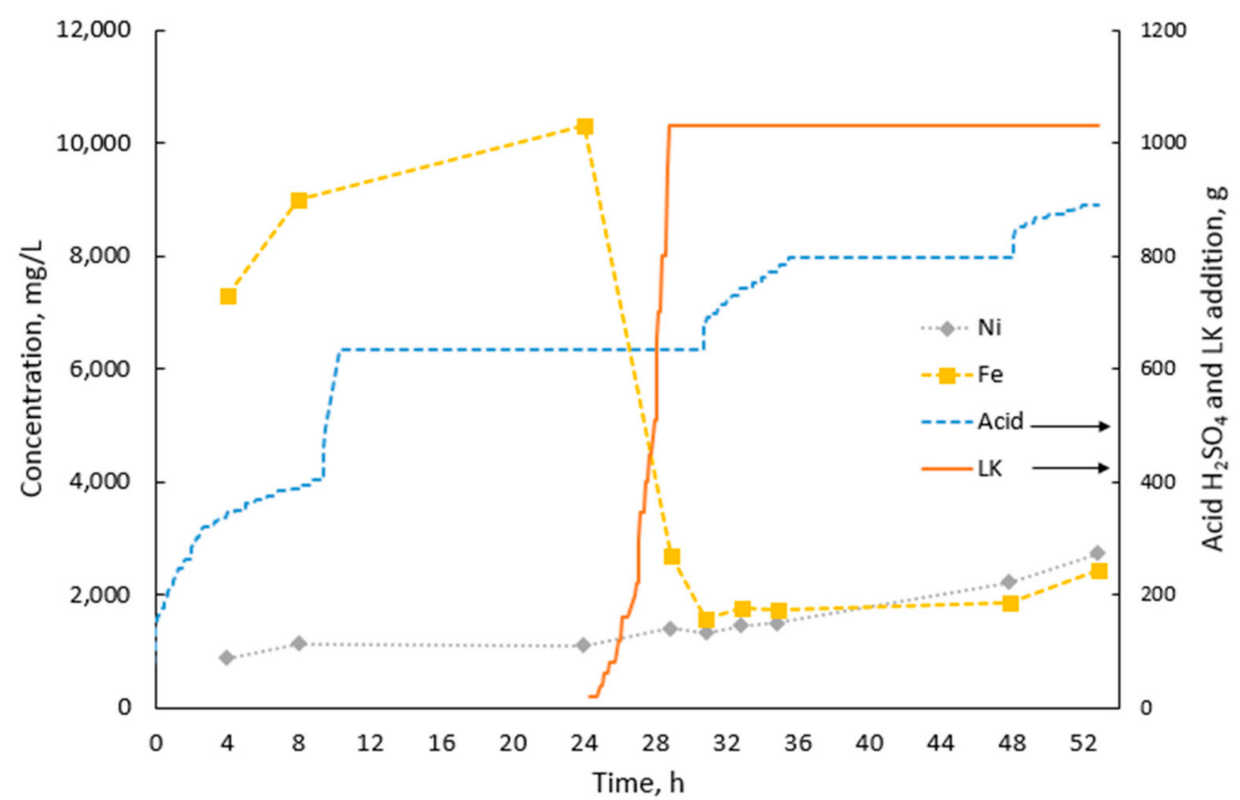

Figure 5. Leaching of LAI for $24 \mathrm{~h}$ at $\mathrm{pH} 0.75$, followed by LK laterite addition increasing the $\mathrm{pH}$ to 1.8. Concentrations of $\mathrm{Ni}, \mathrm{Co}, \mathrm{Fe}$, acid, and LK additions. Parameters used in the experiments: $90{ }^{\circ} \mathrm{C}$, $\mathrm{S} / \mathrm{L}=30 \%, 800 \mathrm{rpm}$.

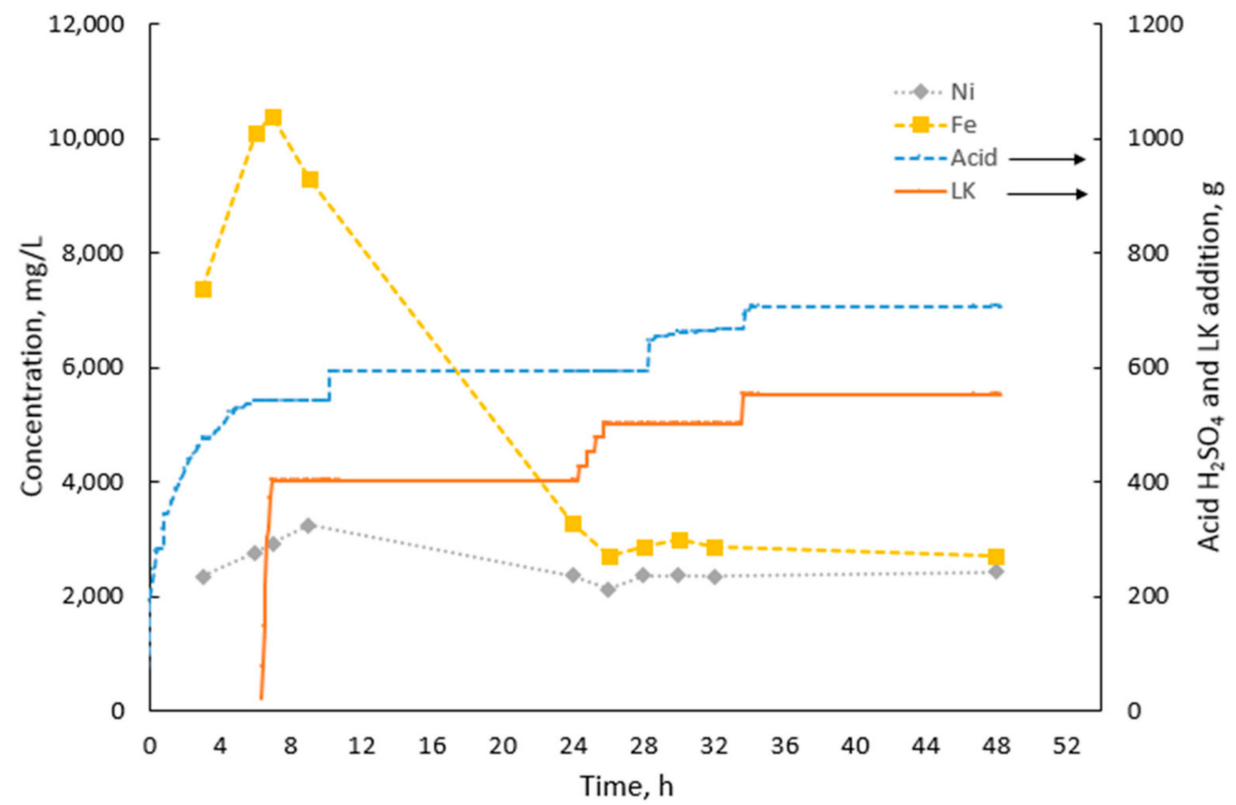

Figure 6. Leaching of LEV for $6 \mathrm{~h}$ at $\mathrm{pH} 0.75$, followed by LK laterite addition increasing the $\mathrm{pH}$ to 1.8. Concentrations of $\mathrm{Ni}, \mathrm{Co}, \mathrm{Fe}$, acid, and LK additions. Parameters used in the experiments: $90{ }^{\circ} \mathrm{C}$, $\mathrm{S} / \mathrm{L}=30 \%, 800 \mathrm{rpm}$. 
Table 7. Efficiency of $\mathrm{H}_{2} \mathrm{SO}_{4}$ leaching of LAI ( $\left.24 \mathrm{~h}\right)$ and LEV (6 h) laterites under the following conditions: $\mathrm{pH} 0.75,90{ }^{\circ} \mathrm{C}, \mathrm{S} / \mathrm{L}=30 \%$, followed by $\mathrm{LK}$ addition to increase $\mathrm{pH}$ to 1.8 (until $48 \mathrm{~h}$ ), by comparing the selectivity of $\mathrm{Ni}$ over $\mathrm{Fe}, \mathrm{Mg}$, and $\mathrm{Al}$ using the respective ratios and concentrations in the PLS.

\begin{tabular}{ccccccccccc}
\hline $\begin{array}{c}\text { Laterite } \\
\text { Ore }\end{array}$ & $\mathbf{p H}$ & $\begin{array}{c}\mathbf{N i} \\
(\mathbf{m g} / \mathrm{L})\end{array}$ & $\begin{array}{c}\mathrm{Co} \\
(\mathbf{m g} / \mathbf{L})\end{array}$ & $\begin{array}{c}\mathbf{F e} \\
(\mathbf{m g} / \mathbf{L})\end{array}$ & $\begin{array}{c}\mathrm{Ca} \\
(\mathbf{m g} / \mathbf{L})\end{array}$ & $\begin{array}{c}\mathbf{M g} \\
(\mathbf{m g} / \mathbf{L})\end{array}$ & $\begin{array}{c}\mathrm{Al} \\
(\mathbf{m g} / \mathbf{L})\end{array}$ & $\mathbf{N i} / \mathrm{Fe}$ & $\mathbf{N i} / \mathbf{M g}$ & $\mathbf{N i} / \mathbf{A l}$ \\
\hline LAI & 0.75 & 1100 & 82 & 10300 & 595 & 1630 & 6040 & 0.11 & 0.68 & 0.18 \\
LAI + LK & 1.8 & 2220 & 124 & 1850 & 456 & 24100 & 2000 & 1.2 & 0.09 & 1.11 \\
LEV & 0.75 & 2770 & 119 & 10100 & - & 6510 & 4560 & 0.27 & 0.43 & 0.61 \\
LEV + LK & 1.8 & 2430 & 94 & 2710 & - & 19300 & 2520 & 0.90 & 0.13 & 0.96 \\
\hline
\end{tabular}

The $\mathrm{Ni} / \mathrm{Fe}$ ratio that defines selectivity, when LAI was separately leached at $\mathrm{pH} 0.75$, was 0.11 . Komnitsas et al. [13] also studied leaching of ore from a similar origin. Their column leaching test for a lower grade Agios Ioannis ore $(0.58 \% \mathrm{Ni})$ resulted in $\mathrm{Ni} / \mathrm{Fe}$ ratios varying between 0.15 and 0.24 . Mystrioti et al. [23] applied a counter-current mode of operation for $\mathrm{HCl}$ leaching of a similar ore which suppressed iron dissolution to $0.6 \%$. However, they found out that the operation had a negative effect on $\mathrm{Ni}$ and Co extraction, which was limited to $55 \%$ and $63 \%$, respectively. At the moment, the sulfuric acid leaching approach applied in this study appears to be more favorable in terms of Ni leaching.

Nickel concentration after leaching at pH 0.75 was $1100 \mathrm{mg} / \mathrm{L}$ for LAI and $2770 \mathrm{mg} / \mathrm{L}$ for LEV. This is in line with the dissolution results after $8 \mathrm{~h}$ leaching. Ni concentrations for LAI were $401 \mathrm{mg} / \mathrm{L}$ at $\mathrm{pH} 1.5$ and $1810 \mathrm{mg} / \mathrm{L}$ at $\mathrm{pH} 0.5$. Ni concentrations for LEV were $845 \mathrm{mg} / \mathrm{L}$ at $\mathrm{pH} 1.5$ and $3510 \mathrm{mg} / \mathrm{L}$ at $\mathrm{pH}$ 0.5. After $48 \mathrm{~h}$ leaching, Ni concentrations were $2220 \mathrm{mg} / \mathrm{L}$ for LAI $+\mathrm{LK}$ and $2430 \mathrm{mg} / \mathrm{L}$ for LEV + LK.

Acid additions of the combined tests are presented in Table 8. Acid additions were $370 \mathrm{~kg}$ sulfuric acid per $1 \mathrm{t}$ ore for the LAI + LK test and $420 \mathrm{~kg}$ sulfuric acid per $1 \mathrm{t}$ ore for the LAI + LK test, whereas in direct acid leaching acid additions were approximately 500-900 kg sulfuric acid per $1 \mathrm{t}$ laterite ore. Acid consumptions calculated using solution analyses were quite close to the actual acid consumptions. The calculated acid consumption in the LAI + LK test was $415 \mathrm{~kg}$ sulfuric acid per $\mathrm{t}$ ore, and in the LEV + LK test the acid consumption was 322 sulfuric acid per $t$ ore. Calculated acid consumptions in direct leaching was 400-500 kg sulfuric acid per t ore for LAI and LEV laterites and $900 \mathrm{~kg}$ sulfuric acid per $t$ ore for LK laterite. Reduction of acid consumption and iron concentration is significant. Furthermore, the obtained acid consumptions are competitive to those in Komnitsas et al.'s [13] column leaching tests for Agios Ioannis ore, which is lower in Ni grade. Their acid consumptions were $0.69-0.76 \mathrm{~kg}$ sulfuric acid per $1 \mathrm{~kg}$ ore, when nickel extractions were $60.2-73.5 \%$.

Table 8. Cumulative acid consumptions $\left(\mathrm{H}_{2} \mathrm{SO}_{4} \mathrm{~kg} / \mathrm{t}\right.$ dry ore) from $\mathrm{H}_{2} \mathrm{SO}_{4}$ leaching of LAI ( $\left.24 \mathrm{~h}\right)$ and LEV $\left(6 \mathrm{~h}\right.$ ) laterites under the following conditions: $\mathrm{pH} 0.75,90^{\circ} \mathrm{C}, \mathrm{S} / \mathrm{L}=30 \%$, followed by $\mathrm{LK}$ addition to increase $\mathrm{pH}$ to 1.8 (until $48 \mathrm{~h}$ ).

\begin{tabular}{cccc}
\hline Laterite & $\mathbf{p H}$ & Time, $\mathbf{h}$ & $\mathbf{H}_{\mathbf{2}} \mathbf{S O}_{\mathbf{4}} \mathbf{~ k g} / \mathbf{t}$ Dry Ore \\
\hline LAI & 0.75 & 24 & 565.25 \\
LAI + LK & 1.8 & 48 & 369.69 \\
LEV & 0.75 & 6 & 481.71 \\
LEV + LK & 1.8 & 48 & 421.94 \\
\hline
\end{tabular}

At the end of the precipitation phase, iron yield to solution in the LAI + LK test was $1.4 \%$, and in the LEV + LK test it was $2.8 \%$. However, nickel yield to solution was not as high in the combined leaching and iron precipitation tests as in direct acid leaching of the laterites. The iron precipitation as jarosite in the LEV + LK and LAI + LK tests was verified by XRD analysis from the leach residues. The XRD analyses showed that iron was precipitated as sodium jarosite $\left(\mathrm{NaFe}_{3}\left(\mathrm{SO}_{4}\right)_{2}(\mathrm{OH})_{6}\right)$ in both cases. Based on the calculations in Table 3, it is assumed that the major acid-consuming element in the 
two-stage leaching approach is aluminum. This is consistent with the fact that iron precipitated as sodium jarosite and not sodium alunite.

Leach residues contained also iron oxides, gypsum $\left(\mathrm{CaSO}_{4} \cdot 2 \mathrm{H}_{2} \mathrm{O}\right)$, and quartz $\left(\mathrm{SiO}_{2}\right)$. Hematite was the main form of iron oxide, but some goethite was found from the leach residue of the LAI + LK leaching test.

This study's aim was to investigate the simultaneous nickel leaching and jarosite precipitation as a phenomenon. The overall aim was to improve the feasibility of atmospheric acid leaching by combining different types of laterites and specifically using a low-grade silicate laterite for neutralization. Using a low-grade laterite for neutralization decreases the need for limestone to enable iron precipitation, while also dissolving some additional nickel from the low-grade laterite. This study is the first step in the laterite process development project and the results presented here will be used for designing a pilot test run. In future research, the feasibility of the process will be further investigated. The aim is to find process conditions, which allow maximizing nickel yield while minimizing acid consumption and final iron concentration in the pregnant leach solution.

\section{Conclusions}

A process involving atmospheric acid leaching of nickel laterites and simultaneous iron precipitation was investigated for the treatment of Greek LAI, LEV, and LK laterites. It was observed that iron control is possible when nickel leaching is combined with jarosite precipitation These tests involved two steps, namely, (i) acidic leaching of LAI or LEV laterite at $\mathrm{pH} 0.75$ and (ii) leaching of nickel from LK laterite in higher $\mathrm{pH}$ with simultaneous iron precipitation as jarosite. The aim of the jarosite precipitation is to decrease iron concentration in the leaching solution and at the same time to use the acid generated from the iron precipitation to obtain a higher nickel dissolution.

Atmospheric acid leaching tests of LAI, LEV, and LK laterite samples in $8 \mathrm{~h}$ experiments showed that $\mathrm{pH}$ lower than 1.5 was needed to effectively dissolve Ni from LAI and LEV, while Ni dissolved from LK already at $\mathrm{pH}$ 1.5. The potential for combined nickel leaching and iron precipitation was observed after $8 \mathrm{~h}$ of leaching. Based on the results, combined leaching and precipitation tests were planned. Tests began by leaching LAI $(24 \mathrm{~h})$ or LEV $(6 \mathrm{~h})$ laterites at $\mathrm{pH} 0.75$, followed by increasing $\mathrm{pH}$ to 1.8 by LK laterite addition.

Acid consumption of atmospheric laterite leaching was high and the $8 \mathrm{~h}$ leaching tests showed that approximately 600-800 g acid per $1 \mathrm{~kg}$ laterite was needed for the Greek laterite samples LAI, $\mathrm{LEV}$, and LK for an efficient nickel dissolution. The combined leaching and precipitation process has a potential to reduce acid consumption and decreased iron removal costs. Consumptions were $0.37 \mathrm{~kg}$ sulfuric acid per $1 \mathrm{~kg}$ for the LAI + LK test and $0.42 \mathrm{~kg}$ sulfuric acid per $1 \mathrm{~kg}$ for the LAI + LK test. Iron concentration decreased from $10 \mathrm{~g} / \mathrm{L}$ to approximately $2-3 \mathrm{~g} / \mathrm{L}$ during the jarosite precipitation stage. That indicates significant savings in iron removal costs since, in the conventional process, all dissolved iron has to be precipitated out from the leach solution using lime or limestone.

Author Contributions: V.M. and L.R. designed the experiments and critically analyzed the results. E.K. and V.M. provided industrial insight to the study. J.M. performed the literature review for the paper. L.R. supervised the carrying out of the experiments. T.K. studied the mineralogy of the samples. V.M. and L.R. wrote the paper in cooperation with the co-authors.

Funding: The authors would like to acknowledge the financial support of the European Commission in the frame of the Horizon 2020 project intitled "Metal recovery from low-grade ores and wastes", www.metgrowplus.eu, Grant Agreement No. 690088.

Acknowledgments: The authors would like to acknowledge the GMM LARCO SA Mines for providing laterite samples used in the leaching tests.

Conflicts of Interest: The authors declare no conflict of interest. 


\section{References}

1. Mudd, G.M. Global trends and environmental issues in nickel mining: Sulfides versus laterites. Ore Geol. Rev. 2010, 38, 9-26. [CrossRef]

2. Barnett, S. Nickel-A key material for innovation in a sustainable future. In Proceedings of the 2nd Euro Nickel Conference, London, UK, 18-19 March 2010; Informa Pty Ltd.: London, UK.

3. McRae, M.E. Minerals Yearbook, Nickel (Advance Release); U.S. Geological Survey: Reston, VA, USA, June 2018.

4. European Commission. Commission Staff Working Document. Report on Raw Materials for Battery Applications. Available online: https://ec.europa.eu/transport/sites/transport/files/3rd-mobility-pack/ swd20180245.pdf (accessed on 24 March 2019).

5. McRae, M.E. Nickel: U.S. Geological Survey, Mineral Commodity Summaries 2018. U.S. Department of Interior, U.S. Geological Survey; pp. 112-113. Available online: https://min-erals.usgs.gov/minerals/pubs/ mcs/2018/mcs2018.pdf (accessed on 24 March 2019).

6. McDonald, R.G.; Whittington, B.I. Atmospheric acid leaching of nickel laterites review Part, I. Sulfuric acid technologies. Hydrometallurgy 2008, 91, 35-55. [CrossRef]

7. Sudol, S. The thunder from down under: everything you wanted to know about laterites but were afraid to ask. Can. Min. J. 2005, 126, 8-12.

8. Oxley, A.; Smith, M.; Caceres, O. Why heap leach nickel laterites? Miner. Eng. 2016, 88, 53-60. [CrossRef]

9. Li, G.; Zhou, Q.; Zhu, Z.; Luo, J.; Rao, M.; Peng, Z.; Jiang, T. Selective leaching of nickel and cobalt from limonitic laterite using phosphoric acid: An alternative for value-added processing of laterite. J. Clean. Prod. 2018, 189, 620-626. [CrossRef]

10. Whittington, B.I.; Muir, D. Pressure Acid Leaching of nickel Laterites: A Review. Miner. Process. Extr. Metall. Rev. 2000, 21, 527-599. [CrossRef]

11. Dalvi, A.D.; Bacon, W.G.; Osborne, R.C. The Past and Future of Nickel Laterites, PDAC 2004 Convention, March 7-10, 2004. Available online: http://citeseerx.ist.psu.edu/viewdoc/download?doi=10.1.1.732.7854\& rep=rep1\&type $=$ pdf (accessed on 24 March 2019).

12. Rodrigues, F.; Pickles, C.A. Factors Affecting the Upgrading of a Nickeliferous Limonitic Laterite Ore by Reduction Roasting, Thermal Growth and Magnetic Separation. Minerals 2017, 7, 176. [CrossRef]

13. Komnitsas, K.; Petrakis, E. Column Leaching of Greek Low-Grade Limonitic Laterites. Minerals 2018, 8, 377. [CrossRef]

14. Agatzini-Leonardou, S. Hydrometallurgical Process for the separation and recovery of nickel from sulfate heap leach liquor of nickelferrous latetrite ores. Miner. Eng. 2009, 22, 1181-1192. [CrossRef]

15. Komnitsas, K.; Petrakis, E.; Bartzas, G.; Karmali, V. Column leaching of low-grade saprolitic laterites and valorization of leaching residues. Sci. Total Environ. 2019, 665, 347-357. [CrossRef] [PubMed]

16. Wang, K. Iron, Aluminium and chromium co-removal from atmospheric nickel laterite leach solutions. Miner. Eng. 2018, 116, 35-45. [CrossRef]

17. Cheng, C.Y. Purification of synthetic laterite leach solution by solvent extraction using D2EHPA. Hydrometallurgy 2000, 56, 369-386. [CrossRef]

18. Arroyo, J.C.; Neudorf, D.A. Atmospheric Leaching Process for the Recovery of Nickel and Cobalt from Limonite and Saprolite Laterite Ores. Patent no: 6,261,527, 2001.

19. Leppinen, J.; Riihimäki, T.; Ruonala, M. Method for Separating Nickel from Material with Low Nickel Content. Patent no: CA2819224A1, 2011.

20. White, D.T.; Gillaspie, J.D. Acid leaching of nickel laterites with jarosite precipitation. In Ni-Co 2013; Springer: Cham, Switzerland, 2013; pp. 75-95.

21. Dutrizac, J.E. The effectiveness of jarosite species for precipitating sodium jarosite. Jom 1999, 51, 30-32. [CrossRef]

22. Das, G.K.; Acharya, S. Jarosites: A Review. Miner. Process. Extr. Metall. Rev. 1996, 16, 185-210. [CrossRef]

23. Mystrioti, C.; Papassiopi, N.; Xenidis, A.; Komnitsas, K. Counter-Current Leaching of Low-Grade Laterites with Hydrochloric Acid and Proposed Purification Options of Pregnant Solution. Minerals 2018, 8, 599. [CrossRef]

(C) 2019 by the authors. Licensee MDPI, Basel, Switzerland. This article is an open access article distributed under the terms and conditions of the Creative Commons Attribution (CC BY) license (http://creativecommons.org/licenses/by/4.0/). 